\title{
Racial Variation in the Relationship of Glycemic Control with Fracture Risk in Elderly Patients with Diabetes
}

This article was published in the following Dove Press journal: Diabetes, Metabolic Syndrome and Obesity: Targets and Therapy

\author{
M Kathleen Figaro' \\ Dustin M Long ${ }^{2}$ \\ Michael E May ${ }^{3}$ \\ Harrison Ndetan ${ }^{4}$ \\ Alan Cook (iD) ${ }^{4}$ \\ Rebecca Baqiyyah Conway ${ }^{4,5}$ \\ 'Heartland Endocrine Group, Davenport, \\ IA, USA; ${ }^{2}$ Department of Biostatistics, \\ University of Alabama at Birmingham, \\ Birmingham, AL, USA; ${ }^{3}$ Department of \\ Medicine, Vanderbilt University, \\ Nashville, TN, USA; ${ }^{4}$ Department of \\ Epidemiology and Biostatistics, University \\ of Texas Health Science Center at Tyler, \\ Tyler, TX, USA; ${ }^{5}$ Department of \\ Community Health, University of Texas \\ Health Science Center at Tyler, Tyler, \\ TX, USA
}

\begin{abstract}
We investigated racial variation in glycemic control (glycated hemoglobin A1c $[\mathrm{HbAlc}])$ with fracture risk in geriatric patients with diabetes. Compared to an $\mathrm{HbA} 1 \mathrm{c}$ of $7.0-7.9 \%$ [53-63 mmol $/ \mathrm{mol}], \mathrm{HbAlc} \geq 9.0 \%$ [ $\geq 75 \mathrm{mmol} / \mathrm{mol}]$ was associated with increased fracture risk among Blacks and those of Unknown race only. This increase was attenuated in Blacks after accounting for the relative frequency of patient-provider interaction.
\end{abstract}

Keywords: diabetes, fragility fractures, glycemic control, racial differences, African Americans

\section{Introduction}

We have previously documented increased fracture risk among geriatric diabetic patients whose glycated hemoglobin A1c (HbA1c) tends to abide either in the very low $(<6.5 \%)$ or high range $(\geq 9.0 \%) .{ }^{1}$ Though non-Whites, and particularly African Americans, are at a decreased risk of fractures compared to US Whites, ${ }^{2-5}$ diabetes and factors associated with it such as poor glycemic control may modify the extent of this protective relationship. As the frequency and depth of patient-provider interaction may vary by race and play a role in both glycemic control and risk of fracture, we investigated whether the association of glycemic control with risk of fracture varies by race.

\section{Research Design and Methods}

Data on a cohort of 99,241 patients with diabetes who were over the age of 65 years were retrieved from the Synthetic Derivative. The Synthetic Derivative is a deidentified, non-relinkable copy of Vanderbilt University Medical Center's electronic health record. ${ }^{6,7}$ This research was approved by the Institutional Review Board of Vanderbilt University.

To be included in the current study, patients had to be at least 65 years old, have an ICD-9 code for diabetes (ICD 9 code 250-250.9), and have at least two HbA1c values at or after the latter of six months prior to age 65 years or ICD-9 code for diabetes. To identify fracture cases we used ICD-9 codes 820-829 or 733. All fracture ICD-9 codes had to be time stamped with a date after that of the HbA1c values. A detailed description of this algorithm has been published previously. ${ }^{1}$ The final population for this study included 10,572 patients with diabetes and at least two $\mathrm{HbAlc}$ values prior to fracture or censoring.
Correspondence: Rebecca Baqiyyah Conway

Department of Community Health, University of Texas Health Science Center at Tyler, II 937 US Highway 27I, Suite \#H250, Tyler, TX 75708, USA

Tel + | 4|2-72I-2779

Email rebeccabnconway@yahoo.com 
We tested whether the association of updated mean HbA1c with fracture risk varied by race (White, African American, Other race, Unknown race) using Cox survival analysis with age as the time scale. HbAlc was modeled in groups defined by clinically relevant $\mathrm{HbA} 1 \mathrm{c}$ levels: $<6.5 \%$ [<48 mmol $/ \mathrm{mol}] ; 6.5-6.9 \%$ [48-52 $\mathrm{mmol} / \mathrm{mol}] ; 7.0-7.9 \%$ [53-63 mmol/mol]; 8.0-8.9\% [64-74 mmol-mol]; $\geq 9.0 \%$ $[\geq 75 \mathrm{mmol} / \mathrm{mol}]$. Our multivariable models included updated mean $\mathrm{HbA1c}$, race, sex (Model1) as well as further controlling for number of BMI measurements (Model2). We used the number of BMI measurements as a surrogate for the relative frequency of outpatient visits with a provider. Updated mean $\mathrm{HbA1c}$ was defined as the average of all $\mathrm{HbA} 1 \mathrm{c}$ values from baseline and follow-up. The criterion for statistical significance was a p-value $<0.05$. Statistical analyses were conducted using SAS version 9.3 (Cary, North Carolina).

\section{Results}

Mean age at study baseline was 72 years. Fifty-one percent of the population was female, $73 \%$ were White, $15 \%$ were African American, 2\% were identified to be of other racial background, and $10 \%$ of the patients had no documented race (Unknown race).
During an average of 3.3 years, there were 756 fracture events in Whites, 146 events in African Americans, 22 events among those of Unknown race, and 25 events in those classified as Other race. Stratified analyses revealed that the statistically significant risk associated with an updated mean $\mathrm{HbAlc} \geq 9.0 \%$ was only observed in African Americans ( $\mathrm{HR}=2.04,95 \% \mathrm{CI}=1.28-3.26)$ and Unknown race $(\mathrm{HR}=4.64,95 \% \mathrm{CI}=1.04-20.77)$, though controlling for the number of BMI measurements greatly attenuated this excess risk in African Americans ( $\mathrm{HR}=1.48,95 \%$ $\mathrm{CI}=0.92-2.39$ ). The multivariable adjusted risk of $\mathrm{HbAlc}$ with fracture risk stratified by race is presented in Table 1.

\section{Discussion}

We evaluated the relationship of glycemic control with fracture risk among a multi-ethnic cohort of geriatric patients with diabetes receiving treatment at Vanderbilt University Medical Center. In this population, the association of A1c with fracture risk was greater in those of nonwhite race. We have previously reported that an average $\mathrm{HbAlc}$ residing in the $6.5-6.9 \%$ range during follow-up was associated with the lowest fracture risk. ${ }^{1}$ Herein we show that African Americans and those of Unknown and Other race, had a higher risk of fracture if their HbAlc

Table I Updated Mean HbAlc and Fracture Risk, Stratified by Race, in Geriatric Patients with Diabetes

\begin{tabular}{|c|c|c|c|c|c|c|c|c|}
\hline & \multicolumn{2}{|c|}{$\begin{array}{l}\text { Whites, n=7757, } \\
\text { Events }=756\end{array}$} & \multicolumn{2}{|c|}{ Blacks, $n=\mid 559$, Events $=\mid 46$} & \multicolumn{2}{|c|}{$\begin{array}{l}\text { Unknown, } n=1007 \text {, } \\
\text { Events=22 }\end{array}$} & \multicolumn{2}{|c|}{$\begin{array}{l}\text { Other, } n=241 \text {, } \\
\text { Events }=25\end{array}$} \\
\hline & Model I & Model 2 & Model I & Model I & Model 2 & Model 2 & Model I & Model 2 \\
\hline $\begin{array}{l}\text { HbAlc } \\
\text { category }\end{array}$ & $\begin{array}{l}\mathrm{HR} \\
(95 \% \mathrm{Cl})\end{array}$ & $\begin{array}{l}\mathrm{HR} \\
(95 \% \mathrm{Cl})\end{array}$ & $\begin{array}{l}\mathrm{HR} \\
(95 \% \mathrm{Cl})\end{array}$ & $\begin{array}{l}\mathrm{HR} \\
(95 \% \mathrm{Cl})\end{array}$ & $\begin{array}{l}\mathrm{HR} \\
(95 \% \mathrm{Cl})\end{array}$ & $\begin{array}{l}\mathrm{HR} \\
(95 \% \mathrm{Cl})\end{array}$ & $\begin{array}{l}\mathrm{HR} \\
(95 \% \mathrm{Cl})\end{array}$ & $\begin{array}{l}\mathrm{HR} \\
(95 \% \mathrm{Cl})\end{array}$ \\
\hline$<6.5 \%$ & $\begin{array}{l}0.96 \\
(0.80-1.15)\end{array}$ & $\begin{array}{l}0.99 \\
(0.83-1.19)\end{array}$ & $\begin{array}{l}0.85 \\
(0.53-1.37)\end{array}$ & $\begin{array}{l}0.80 \\
(0.50-1.28)\end{array}$ & $\begin{array}{l}1.14 \\
(0.35-3.64)\end{array}$ & $\begin{array}{l}1.25 \\
(0.39-4.04)\end{array}$ & $\begin{array}{l}1.06 \\
(0.36-3.16)\end{array}$ & $\begin{array}{l}0.80 \\
(0.26-2.46)\end{array}$ \\
\hline $6.5-<7.0 \%$ & $\begin{array}{l}0.80 \\
(0.65-0.99)\end{array}$ & $\begin{array}{l}0.84 \\
(0.68-1.04)\end{array}$ & $\begin{array}{l}0.67 \\
(0.39-1.13)\end{array}$ & $\begin{array}{l}0.69 \\
(0.40-1.16)\end{array}$ & $\begin{array}{l}0.98 \\
(0.28-3.45)\end{array}$ & $\begin{array}{l}\text { I.29 } \\
(0.36-4.63)\end{array}$ & $\begin{array}{l}0.18 \\
(0.02-1.45)\end{array}$ & $\begin{array}{l}0.18 \\
(0.02-1.50)\end{array}$ \\
\hline $7.0-<8.0 \%$ & Ref & Ref & Ref & Ref & Ref & Ref & Ref & Ref \\
\hline $8.0-<9.0 \%$ & $\begin{array}{l}1.26 \\
(1.00-1.60)\end{array}$ & $\begin{array}{l}1.18 \\
(0.93-1.49)\end{array}$ & $\begin{array}{l}0.95 \\
(0.57-1.57)\end{array}$ & $\begin{array}{l}0.89 \\
(0.53-1.47)\end{array}$ & $\begin{array}{l}0.83 \\
(0.16-4.36)\end{array}$ & $\begin{array}{l}1.27 \\
(0.24-6.74)\end{array}$ & $\begin{array}{l}1.98 \\
(0.66-5.96)\end{array}$ & $\begin{array}{l}\text { I.34 } \\
(0.4 \mid-4.30)\end{array}$ \\
\hline$\geq 9 \%$ & $\begin{array}{l}1.27 \\
(0.92-1.76)\end{array}$ & $\begin{array}{l}1.01 \\
(0.73-1.40)\end{array}$ & $\begin{array}{l}2.04 \\
(1.28-3.26)\end{array}$ & $\begin{array}{l}1.48 \\
(0.92-2.39)\end{array}$ & $\begin{array}{l}4.64 \\
(1.04-20.77)\end{array}$ & $\begin{array}{l}4.17 \\
(0.92-18.88)\end{array}$ & $\begin{array}{l}2.00 \\
(0.48-8.34)\end{array}$ & $\begin{array}{l}1.19 \\
(0.27-5.29)\end{array}$ \\
\hline Sex, female & $\begin{array}{l}1.71 \\
(1.48-1.99)\end{array}$ & $\begin{array}{l}1.67 \\
(1.44-1.94)\end{array}$ & $\begin{array}{l}1.74 \\
(1.17-2.60)\end{array}$ & $\begin{array}{l}1.79 \\
(1.20-2.68)\end{array}$ & $\begin{array}{l}3.09 \\
(1.11-8.55)\end{array}$ & $\begin{array}{l}3.50 \\
(1.25-9.76)\end{array}$ & $\begin{array}{l}1.52 \\
(0.64-3.62)\end{array}$ & $\begin{array}{l}I .79 \\
(0.72-4.42)\end{array}$ \\
\hline $\begin{array}{l}\text { Number of } \\
\text { BMI } \\
\text { measurements }\end{array}$ & 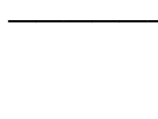 & $\begin{array}{l}0.97 \\
(0.96-0.97)\end{array}$ & $\longrightarrow$ & $\begin{array}{l}0.97 \\
(0.96-0.98)\end{array}$ & & $\begin{array}{l}0.84 \\
(0.74-0.95)\end{array}$ & - & $\begin{array}{l}0.94 \\
(0.90-0.97)\end{array}$ \\
\hline
\end{tabular}


was $>9.0 \%$ compared to having an HbAlc in the $7.0-7.9 \%$ range, an elevated risk which was not observed in Whites.

We speculate that the frequency and intensity of the patient-provider interaction and the social support of the patient may account for our findings. The association between high $\mathrm{HbAlc}$, fracture risk and race was moderated by number of BMI measurements. Although our data were minimally adjusted, only accounting for age, sex and the number of BMI measurements in the association of $\mathrm{HbA1c}$ with fracture, we speculate that the number of BMI measurements is a marker of the relative frequency of outpatient care events or the intensity of healthcare the patient is receiving. The number of BMI measures was associated with a lower risk of fracture among all racial groups and accounting for the number of BMI measurements attenuated the association of a high HbAlc in each of these groups. This was particularly marked in African Americans. Those of Unknown race had the greatest risk of fracture associated with a high $\mathrm{HbAlc}$, the fewest BMI measurements, and the greatest protection associated with the number of BMI measurements. In summary, lack of diabetes control is associated with increased fracture risk, a risk particularly pronounced among non-White patients. Our data also suggest the frequency of patient-provider interaction has an impact on fracture risk in geriatric patients and confounds the association of high $\mathrm{HbAlc}$ with fracture risk, particularly among African Americans.

\section{Funding}

This study was supported in part by the West Virginia University grant CTSI grant U54GM104942 from the
National Institutes of Health (NIH) and the Vanderbilt University CTSA grant UL1 TR00445 from NCATS/NIH.

\section{Disclosure}

The authors report no conflicts of interest in this work.

\section{References}

1. Conway BN, Long DM, Figaro MK, May ME. Glycemic control and fracture risk in elderly patients with diabetes. Diabetes Res Clin Pract. 2016;115:47-53. doi:10.1016/j.diabres.2016.03.009

2. Baron JA, Barrett J, Malenka D, et al. Racial differences in fracture risk. Epidemiology. 1994;5(1):42-47. doi:10.1097/00001648199401000-00008

3. George A, Tracy JK, Meyer WA, Flores RH, Wilson PD, Hochberg MC. Racial differences in bone mineral density in older men. J Bone Miner Res. 2003;18(12):2238-2244. doi:10.1359/ jbmr.2003.18.12.2238

4. Griffin MR, Ray WA, Fought RL, Melton LJ. Black-white differences in fracture rates. Am $J$ Epidemiol. 1992;136(11):1378-1385. doi:10.1093/oxfordjournals.aje.a116450

5. Strotmeyer ES, Cauley JA, Schwartz AV, et al. Diabetes is associated independently of body composition with BMD and bone volume in older white and black men and women: the health, aging, and body composition study. J Bone Miner Res. 2004;19(7):1084-1091. doi:10.1359/JBMR.040311

6. Roden DM, Pulley JM, Basford MA, et al. Development of a large-scale de-identified DNA biobank to enable personalized medicine. Clin Pharmacol Ther. 2008;84(3):362-369. doi:10.1038/ clpt.2008.89

7. Pulley J, Clayton E, Bernard GR, Roden DM, Masys DR. Principles of human subjects protections applied in an opt-out, de-identified biobank. Clin Transl Sci. 2010;3(1):42-48. doi:10.1111/j.17528062.2010.00175.x

\section{Publish your work in this journal}

Diabetes, Metabolic Syndrome and Obesity: Targets and Therapy is an international, peer-reviewed open-access journal committed to the rapid publication of the latest laboratory and clinical findings in the fields of diabetes, metabolic syndrome and obesity research. Original research, review, case reports, hypothesis formation, expert opinion and commentaries are all considered for publication. The manuscript management system is completely online and includes a very quick and fair peer-review system, which is all easy to use. Visit http://www.dovepress.com/testimonials.php to read real quotes from published authors. 